\title{
Effect of Anredera cordifolia (Ten) Steenis Leaves Ethanol Extract in suppressing Brown PlantHopper (Nilaparvata lugens Stal.) Populations on Rice Plant
}

\author{
Martua Suhunan Sianipar ${ }^{1 *}$, Tarkus Suganda ${ }^{1}$ and Azhhar Hadyarrahman ${ }^{2}$ \\ ${ }^{1}$ Department of Plant Pests and Diseases, Agriculture Faculty, Universitas Padjadjaran, Jatinangor, West Java, Indonesia, \\ 45363 \\ ${ }^{2}$ Alumnus Department of Plant Pests and Diseases, Agriculture Faculty, Universitas Padjadjaran, Jatinangor, West Java, \\ Indonesia, 45363 \\ *Corresponding Author: Suhunan@unpad.ac.id
}

Received September 15, 2020; revised September 21, 2020; accepted November 05, 2020

\begin{abstract}
The Brown Planthopper (Nilaparvata lugens Stal.) is one of the pests that often causes rice crop failure in rice. One way to control $N$. lugens pests is to use of botanical insecticide. The purpose of this experiment is to study the effect of $A$. cordifolia leaves ethanol in suppressing $N$. lugens populations. The experiment used a Randomized Block Design (RDB) with 8 treatments and 4 replications. The $A$. cordifolia leaves ethanol extract concentration tested in this experiment consisted of $0,5 \% ; 0,75 \% ; 1 \% ; 1,5 \%$; and $2 \%$. The results of the experiment showed that the ethanol extract of binahong leaves with a concentration of $1 \%, 1.5 \%$ and $2 \%$ cause mortality of $N$. lugens by $52.50 \%, 56.25 \%$, and $61.25 \%$ on the $14^{\text {th }}$ day after application. Based on the results of this experiment, the ethanol extract of A.cordifolia leaves was not effective against $N$. lugen.
\end{abstract}

Keywords: A. cordifolia, concentration, ethanol extract, mortality N. lugens.

\section{ABSTRAK}

Pengaruh Ekstrak Etanol Daun Binahong (Anredera cordifolia (Ten.) Steenis.) dalam Menekan Populasi Wereng Coklat (Nilaparvata Lugens Stal) Pada Tanaman Padi

Wereng Coklat (Nilaparvata lugens Stal) merupakan salah satu hama yang sering menyebabkan gagal panen tanaman padi. Salah satu cara untuk mengendalikan hama Wereng Coklat yaitu dengan menggunakan pestisida nabati. Tujuan percobaan ini untuk mempelajari pengaruh ekstrak etanol daun binahong (Anredera cordifolia (Ten) Steenis) sebagai salah satu bahan insektisida nabati dalam pengendalian Wereng Coklat ( $N$. lugens).Percobaan menggunakan Rancangan Acak Kelompok (RAK) dengan 8 perlakuan dan 4 ulangan. Konsentrasi ekstrak etanol daun binahong yang diuji terdiri atas $0,5 \%, 0,75 \%$, $1 \%, 1,5 \%$, dan $2 \%$. Hasil percobaan menunjukkan bahwa, ekstrak etanol daun binahong dengan konsentrasi $1 \%, 1,5 \%$ dan $2 \%$ mengakibatkan kematian $N$. lugens sebesar 52,50\%, 56,25\%, dan 61,25\% pada hari ke 14 setelah aplikasi. Berdasarkan hasil percobaan ini ekstrak etanol daun A.cordifolia tidak efektif terhadap N. lugens.

Kata Kunci: binahong, ekstrak etanol, konsentrasi, mortalitas N. lugens

\section{PENDAHULUAN}

Padi (Oryza sativa L.) merupakan salah satu komoditas pertanian yang penting dan menempati urutan pertama di Indonesia karena sebagian besar dari penduduk Indonesia mengkonsumsi beras sebagai bahan makanan pokoknya. Permintaan akan beras terus meningkat seiring pertumbuhan jumlah penduduk di Indonesia. Pada tahun 2017, jumlah penduduk Indonesia mencapai 262 juta jiwa dengan rata-rata konsumsi perkapita/tahun mencapai 114,6 kg/kapita/tahun (BPS, 2017). Kondisi ini menunjukkan bahwa kebutuhan masyarakat Indonesia akan beras sangat tinggi seiring bertumbuhnya jumlah penduduk di Indonesia. Pemerintah selalu berupaya meningkatkan produktivitas dalam negeri (Regazzoni et. al., 2013). Produksi padi menurut Badan Pusat Statistik (BPS) pada tahun 2014 sebanyak 70,83 juta ton gabah kering giling (GKG) atau mengalami penurunan sebesar 0,45 juta ton $(0,63 \%)$ dibandingkan tahun 2013 (Anonim, 2015). Penurunan hasil padi tersebut terjadi sebagian besar akibat cuaca dan serangan organisme pengganggu tanaman (OPT).

Wereng Coklat (Nilaparvata lugens Stal) merupakan salah satu hama yang sering mengakibatkan gagal panen pada padi (Ningsih et. al., 2016). Kerusakan yang diakibatkan oleh N. lugens mampu mengakibatkan terjadinya gagal panen (Setyorini et. al., 2013). Nilaparvata lugens dapat merusak tanaman dalam waktu yang relatif singkat padaada semua fase pertumbuhan. $N$. lugens Stal merusak tanaman padi dengan menghisap cairan sel tanaman (Harini et. al.,2013) dan berperan sebagai vektor virus (Gurr et. al., 2010). Harini et. al., (2013) menyatakan bahwa serangan Nilaparvata lugens Stal yang berat dapat mengakibatkan terjadinya puso (Hopperburn). Berbagai varietas padi khususnya padi tipe baru (PTB), padi hibrida dan padi varietas unggul baru (VUB) tidak luput dari serangan hama $N$. lugens 
Stal (Fitriningtyas, 2012). Ledakan hama N. lugens Stal juga dipicu oleh penggunaan insektisida sintetik yang tidak tepat sasaran oleh lebih dari $90 \%$ petani di Indonesia. Data lain menunjukkan bahwa $60 \%$ petani Sekolah Lapangan Pengenalian Hama Terpadu (SLPTH) dan $65 \%$ petani non-SLPHT menggunakan insektisida, baik yang dianjurkan maupun yang tidak dianjurkan secara keliru (Baehaki \& Mejaya, 2014).

Penggunaan insektisida sintetik yang berlebihan dan tidak tepat, tidak akan mampu mengatasi hama namun sebaliknya dapat menimbulkan terjadinya resurgensi hama (Rizkie et. al., 2015). Sutrisno (2014) menyatakan bahwa resistensi Nilaparvata lugens Stal terhadap insektisida merupakan salah satu faktor terjadinya letusan $N$. lugens karena insektisida yang digunakan kurang efektif. Dengan menggunakan pengendalian cara lain seperti dengan pengendalian biologis memanfaatkan musuh alami dan insektisida nabati dapat mengendalikan hama dengan aman dan mampu menjaga keseimbangan ekosistem serta dapat menghindari terjadinya resistensi hama sasaran (Syahrawati et. al., 2010).

Insektisida nabati umumnya tidak langsung mematikan serangga yang diaplikasikan terhadap hama sasaran, namun lebih berfungsi sebagai reppelent yaitu penolak kehadiran serangga terutama karena baunya yang menyengat. Tumbuhan yang memiliki sifat insektisida di antaranya ialah tumbuhan yang mengandung golongan sianida, saponin, tanin, flavonoid, alkaloid, steroid, dan minyak atsiri (Kardinan, 2000).

Tanaman binahong (Anredera cordifolia) merupakan tanaman obat dari dataran Tiongkok yang dikenal dengan nama asli dheng san chi, sedangkan di dunia internasional binahong dikenal dengan nama hearthleaf madeiravine. Di Bali dikenal sebagai gondola, di Madura sebagai kandula, di Jawa sebagai uci-uci, di Minangkabau sebagai lembayung, di Sulawesi Utara sebagai tatabuwe dan sering digunakan sebagai gapura melingkar di atas jalan taman (Hariana, 2013). Menurut Prakash (2001), tanaman binahong termasuk dalam famili Basellaceae yang merupakan salah satu tanaman obat potensial untuk dikembangkan.

Semua bagian dari tanaman binahong dapat dimanfaatkan sebagai obat mulai dari batang, akar, bunga dan daunnya. Namun yang paling sering dimanfaatkan adalah bagian daunnya (Manoi, 2009). Senyawa aktif alkaloid, saponin dan flavonoid terkandung dalam daun binahong (Rochani, 2009). Menurut Wardani et. al., (2010) alkaloid dan saponin merupakan racun perut pada serangga. Alkaloid berperan dalam menghambat tiga hormon serangga yaitu hormon edikson, hormon otak dan hormon juvenil. Akibat penghambatan ini nantinya pertumbuhan serangga akan terganggu dan kemudian mengalami kematian, sedangkan saponin berperan dalam merusak permukaan selaput pada serangga. Senyawa flavonoid sendiri berfungsi sebagai racun pernapasan. Cara kerja flavonoid yaitu dengan masuk ke dalam saluran pernapasan yang nantinya menyerang sistem pernafasan dan sistem saraf, yang akan mengakibatkan serangga sulit bernafas dan akhirnya mati (Robinson, 1995)

Sebelumnya ekstrak daun binahong telah diujikan pada larva Aedes aegypti oleh Putriet. al., (2018) dengan konsentrasi ekstrak daun binahong yang digunakan yaitu $1.0 \%, 2.0 \%, 3.0 \%, 4.0 \%$, dan $5.0 \%$. Hasil penelitian menunjukkan bahwa pada konsentrasi $1.0 \%, 2.0 \%$, dan $3.0 \%$ ekstrak daun binahong mampu mematikan $100 \%$ larva A. aegypti dalam waktu 12 jam, sedangkan pada konsentrasi $4.0 \%$ dan $5.0 \%$, ekstrak daun binahong mampu mematikan $100 \%$ larva dalam waktu 8 jam. Hasil ini menunjukkan bahwa, ekstrak binahong berbahan pelarut etanol dengan konsentrasi di atas $1.0 \%$ mampu mematikan $100 \%$ larva A. aegypti namun dengan waktu yang berbeda.

Mengingat bahwa ekstrak daun binahong memiliki kemampuan insektisida dan bahwa Nilaparvata lugens Stal merupakan hama yang sangat penting pada tanaman padi, serta pengendaliannya dengan insektisida menimbulkan berbagai dampak negatif, maka dirasa perlu untuk menguji pengaruh ekstrak etanol daun binahong ( $A$. cordifolia) dalam menekan populasi Nilaparvata lugens Stal pada tanaman padi.

\section{BAHAN DAN METODE}

Percobaan dilaksanakan di Rumah Kaca Hama Departemen Hama dan Penyakit Tumbuhan, Fakultas Pertanian, Universitas Padjadjaran dengan ketinggian tempat 720 meter dari permukaan laut. Percobaan dilaksanakan pada bulan April 2019 sampai dengan Juli 2019.

\section{Penanaman Tanaman Padi (Oryza sativa)}

Padi yang digunakan adalah varietas IR64. Benih padi disemai sampai berumur 21 hari setelah tanam (HST). Setelah berumur $21 \mathrm{HST}$, benih padi dipindahkan ke ember yang sudah berisi tanah basah sebanyak 4 batang /ember. Tanaman padi yang digunakan untuk perlakuan adalah yang sudah berumur $30 \mathrm{HST}$. Bibit padi untuk perbanyakan $N$. lugens berjumlah 30 bibit padi pada 10 pot, sedangkan untuk pengujian pestisida nabati bibit yang digunakan berjumlah 150 bibit padi pada 50 pot. Setiap pot berisikan 3 bibit padi.

\section{Penyediaan Wereng Coklat ( $N$. lugens)}

Hama Nilaparvata lugens Stal diperoleh dari Balai Besar Penelitian Tanaman Padi, Sukamadi, Subang tahun 2019 yang kemudian dikembangbiakkan (rearing) di Rumah Kaca Hama Fakultas Pertanian Universitas Padjadjaran. Pengembangbiakan dilakukan dengan cara meletakan $N$. lugens pada tanaman padi varietas IR64 yang berumur 30 HST dan ditutup dengan sungkup, dibiarkan hingga bertelur dan menetas. Hama $N$. 
lugens hasil pengembangbiakan yang digunakan adalah pada stadia nimfa instar 3 (berumur 15 hari dari fase telur).

\section{Pembuatan Sungkup}

Sungkup terbuat dari plastik mika yang berbentuk seperti tabung. Sungkup berfungsi untuk menutupi tanaman padi dan $N$. lugens yang berada pada ember tersebut. Bagian atas sungkup ditutupi dengan kain kassa dan diikat dengan tali agar tidak mudah terlepas. Sungkup yang akan dipasangkan memiliki tinggi $50 \mathrm{~cm}$ dengan diameter $25 \mathrm{~cm}$. Pengamatan dilakukan 24 jam setelah aplikasi pestisida nabati dan seterusnya setiap hari selama $N$. lugens masih ada yang hidup.

\section{Penyediaan Ekstrak Binahong (A. cordifolia)}

Daun binahong didapat dari lingkungan Universitas Padjadjaran kampus Jatinangor tahun 2019. Daun binahong sebanyak $3000 \mathrm{~g}$ ditimbang kemudian dicuci menggunakan air hingga bersih lalu dikeringkan. Pengeringan dilakukan menggunakan oven pada suhu $70-80{ }^{\circ} \mathrm{C}$ selama kurang lebih 2 minggu. Daun yang sudah kering, dicacah terlebih dahulu kemudian dihaluskan menggunakan blender kering tanpa menggunakan air. Maserasi dilaksanakan selama 3 hari dengan pelarut etanol $96 \%$. Perbandingan simplisia dan pelarut adalah 1:10. Ekstrak kental diperoleh dari evaporasi filtrat hasil maserasi menggunakan rotary evaporator pada suhu $40^{\circ} \mathrm{C}$ dan $50 \mathrm{rpm}$ (Wientarsih et. al., 2017). Pembuatan larutan yaitu dengan mencampurkan ekstrak daun binahong dengan tween 80 sebanyak $0,03 \%$ dan aquadest sampai $100 \mathrm{ml}$.

\section{Pelaksanaan Percobaan}

Sebelum penginfestasian $N$. lugens, tanaman padi perlakuan disemprot dengan pestisida nabati terlebih dahulu kecuali pada perlakuan kontrol $N$. lugens, tanaman padi disemprotkan dengan pestisida nabati terlebih dahulu kecuali pada perlakuan control. Nilaparvata lugens nimfa instar 3 diinfestasikan ke batang tanaman padi Varietas IR64 yang berumur 30 hari dengan menggunakan aspirator sebanyak 20 ekor perperlakuan. Penyemprotan dilakukan sesuai dengan konsentrasi perlakuan yang telah ditentukan. Penyemprotan dilakukan di luar sungkup agar semua bagian tanaman terkena. Penyemprotan dilakukan sebanyak 6 kali pertanaman.Setelah tanaman diberi perlakuan, 3 menit kemudian $N$. lugens instar 3 diinfestasikan pada setiap tanaman lalu ditutup dengan sungkup.

Peubah yang diamati yaitu mortalitas serangga uji. Pengamatan dilakukan setiap hari mulai dari 24 jam setelah aplikasi pestisida nabati pertama dan diakhiri pada saat nimfa $N$. lugens menjadi imago. Nilaparvata lugens yang mati akibat insektisida nabati dapat dilihat dari warna tubuhnya yang berubah menjadi agak kegelapan atau berwarna coklat kehitaman dan didalam tubuh wereng tersebut tidak terdapat cairan yang dapat menyebabkan bau yang tidak sedap (Tuti et al., 2014). Selain itu juga diukur suhu dan kelembapan rumah kaca menggunakan alat Termohigrometer. Pengamatan suhu dan kelembapan dilakukan setiap hari bersamaan dengan perhitungan jumlah $N$. lugens yang mati setiap harinya.

\section{HASIL DAN PEMBAHASAN}

\section{Mortalitas N. lugens}

Nilaparvata lugens pada tanaman padi yang diberi perlakuan kemudian mati akan jatuh ke tanah dan apabila disentuh tidak memberikan respons. Tubuh $N$. lugens yang mati masih terlihat baik, namun terjadi perubahan warna menjadi lebih gelap dan apabila sudah didiamkan beberapa hari berubah warna menjadi warna putih. Hal tersebut sejalan dengan penelitian Tuti et. al., (2014) yang melaporkan bahwa tubuh wereng coklat yang mati akibat insektisida nabati, tubuhnya masih bagus namun berubah agak kegelapan dan tidak terdapat cairan dalam tubuhnya yang mengakibatkan bau tidak sedap.Selain itu, pada penelitian Sirait (2018), tubuh $N$. lugens yang mati akibat insektisida nabati ditandai dengan perubahan warna menjadi agak kegelapan.

Hasil percobaan menunjukkan bahwa aplikasi ekstrak etanol daun binahong (A. cordifolia) pada padi yang diinfestasi dengan $N$. lugens mampu menyebabkan kematian $N$. lugens hingga 14 hari setelah perlakuan, sedangkan pada pelakuan kontrol, baik perlakuan dengan aquades maupun dengan larutan tween $800,03 \%$ tidak ada $N$. lugens yang mati (Tabel 1).

Pada hari pertama setelah perlakuan, ekstrak etanol daun binahong dengan konsentrasi 0,5\% belum mampu menyebabkan kematian pada $N$. lugens, tetapi pada perlakuan konsentrasi $0.75 \%$ hingga konsentrasi $2.0 \%$ serta perlakuan pestisida sintetik, sudah menyebabkan kematian pada $N$. lugens sejak satu hari setelah perlakuan. Konsentrasi tersebut pada satu hari setelah perlakuan baru dapat menyebabkan kematian masing-masing sebesar $2.5 \%$; $3.75 \% ; 5.0 \%$, dan $7.5 \%$ serta pada perlakuan pestisida sintetik sebesar $11.25 \%$. Pada hari ke dua, semua perlakuan ekstrak etanol daun Binahong telah menyebabkan terjadinya peningkatan kematian $N$. lugens, kematian tertinggi terdapat pada perlakuan konsentrasi $2.0 \%$, yaitu sebesar $12.50 \%$. Senyawa yang terkandung dalam ekstrak etanol daun binahong diduga masuk ke dalam tubuh $N$. lugens sehingga mampu mematikan $N$. lugens. Akan tetapi apabila dibandingkan dengan perlakuan pestisida sintetik dengan bahan aktif Dimehipo 3\%, masih lebih tinggi perlakuan pestisida sintetik sebesar $21,25 \%$ dibandingkan dengan perlakuan konsentrasi $2.0 \%$.

Selanjutnya, data pada Tabel 1 yang terdapat di halaman selanjutnya memperlihatkan bahwa pada hari ke-12 sampai hari ke-14 kematian $N$. lugens 
tertinggi terdapat pada perlakuan konsentrasi ekstrak etanol daun binahong $2.0 \%$ yaitu sebesar $63,75 \%$. Menurut Katno et al. (2006) beberapa senyawa yang terkandung dalam binahong adalah alkaloid, flavonoid, dan saponin.Alkaloid dan flavonoid merupakan racun perut yang mengakibatkan terganggunya sistem pencernaan. Selain itu, senyawa alkaloid dan flavonoid juga mampu mengganggu reseptor perasa pada serangga sehingga serangga mengalami kesulitan mengenali makanannya sehingga pada akhirnya akan menyebabkan kematian serangga karena kelaparan (Mokodompit et al., 2013). Alkaloid juga berperan dalam menghambat tiga hormon utama di dalam serangga.Tiga hormon utama yang dihambat yaitu hormon otak, hormon edikson, dan hormon juvenil serangga. Saat hormon pertumbuhan serangga terhambat, maka pertumbuhannya akan terganggu dan kemudian mati. Selain itu, senyawa flavonoid juga mampu membunuh serangga dengan cara menyerang saluran pernafasannya. Flavonoid bekerja dengan masuk ke dalam saluran pernapasan serangga, yang kemudian akan menyerang saraf dan sistem pernapasannya yang mengakibatkan serangga akan sulit bernafas dan kemudian mati (Robinson, 1995) dan senyawa saponin berfungsi dalam merusak dinding sel pada kulit hama serta menghambat nafsu makan (Efendi, 2018).

Tabel 1. Persentase mortalitas nimfa N. lugens akibat perlakun ekstrak etanol daun binahong

A. cordifolia

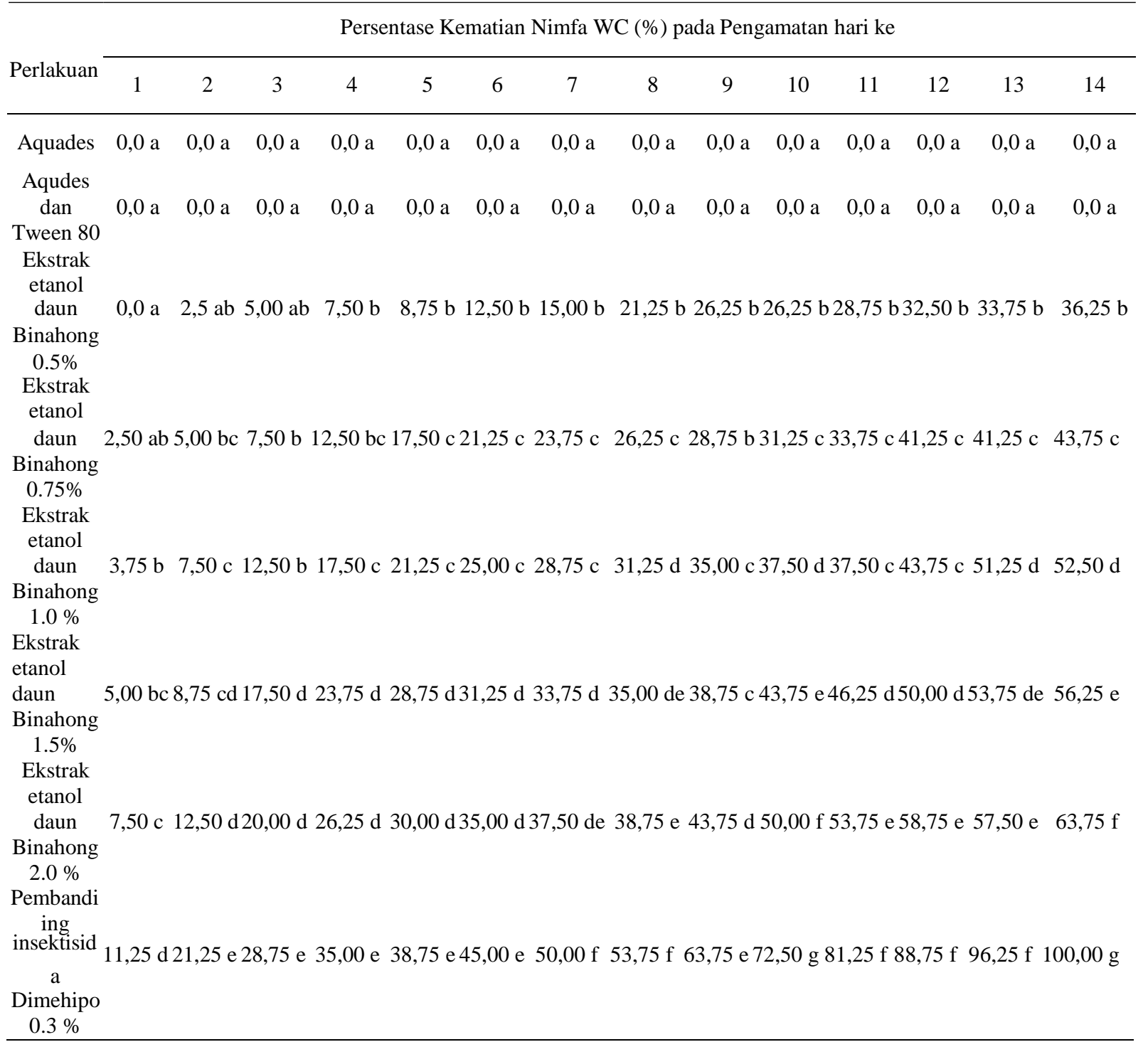

Keterangan: Nilai rata-rata yang diikuti huruf yang sama pada setiap kolom menunjukkan tidak berbeda nyata berdasarkan uji jarak berganda Duncan pada taraf $5 \%$.

Berdasarkan hasil percobaan ini perlakuan dengan konsentrasi ekstrak tertinggi $2 \%$ hanya mengakibatkan mortalitas serangga uji sebesar
63,75\% yang menunjukkan bahwa ekstrak binahong kurang atau tidak efektif terhadap $N$. lugens. Pada perlakuan pestisida sintetik dengan bahan aktif 
Dimehipo $3 \%$ kematian $N$. lugens merupakan kematian tertinggi yaitu sebesar $100 \%$ pada hari ke14. Menurut Anonim (2012) insektisida berbahan aktif Dimehipo merupakan insektisida dengan cara kerja racun kontak, namun bisa juga menjadi racun sistemik saat masuk ke dalam tubuh serangga yang berbentuk pekatan yang dapat larut di dalam air dan berwarna kemerahan. Selain itu, menurut Anonim (2011), insektisida berbahan aktif Dimehipo ini ditujukan untuk pengendalian hama padi seperti kelompok pengisap batang/pelepah daun seperti salah satunya wereng coklat.

Kematian $N$. lugens pada perlakuan pestisida sintetik lebih tinggi dibandingkan dengan perlakuan ekstrak etanol daun binahong. Hal ini dikarenakan perbedaan cara kerja dari keduanya. Pestisida sintetik yang digunakan sebagai pembanding diketahui memiliki cara kerja sebagai racun kontak, sehingga apabila senyawa tersebut langsung mengenai bagian tubuh hama $N$. lugens tersebut, maka serangga akan mati. Menurut Dadang (2006), racun kontak berarti pestisida tersebut masuk melalui kontak ataupun masuk ke tubuh serangga melalui dinding tubuh atau kutikula. Berbeda dengan pestisida sintetik, ekstrak etanol daun binahong yang merupakan pestisida nabati biasanya merupakan racun perut. Racun perut bekerja efektif apabila senyawa dari ekstrak daun binahong masuk ke dalam saluran pencernaan $N$. lugens melalui proses makanan yang dikonsumsinya.

Menurut Watanabe \& Kitagawa (2000), N. lugens merupakan serangga dengan tipe mulut penusuk dan penghisap terutama menghisap cairan floem, mengurangi klorofil dan kandungan daun, serta mengurangi laju fotosintetis. Imago dan nimfa $N$. lugens menghisap cairan tanaman yang mengakibatkan tanaman menjadi kerdil, daun menguning, layu dan akhirnya mati kering (Baehaki \& Mejaya, 2014). Pestisida mampu diserap oleh bagian-bagian tanaman melalui stomata, meristem akar, lentisel batang dan celah-celah alami yang selanjutnya akan melewati sel-sel menuju ke jaringan pengangkut baik itu xilem ataupun floem (Tricahyono, 2016). Selain itu, pestisida nabati umumnya hanya memiliki daya racun yang rendah atau memiliki efek yang lambat dibandingkan dengan pestisida sintetik (Wisuda, 2015). Menurut Kardinan (2000), insektisida nabati lebih berfungsi sebagai penolak kehadiran serangga yang tidak langsung mematikan serangga sasaran.

Kematian serangga uji semakin tinggi seiring dengan semakin tingginya konsentrasi yang diberikan (Tabel 1). Hal ini disebabkan semakin tinggi konsentrasi yang diberikan, semakin tinggi pula kandungan senyawa bioaktifnya. Menurut Ismatullah (2012) dan Kurniawati et. al., (2015) bahwasemakin tinggi konsentrasi ekstrak yang diberikan maka akan semakin banyak zat toksik yang masuk ke dalam tubuh serangga sehingga semakin cepat waktu untuk mengakibatkan kematian $100 \%$ pada serangga uji.
Meningkatnya konsentrasi zat yang masuk ke dalam tubuh $N$. lugens sehingga melebihi batas toleransinya dapat mengakibatkan kematian.

\section{Suhu dan Kelembapan Rumah Kaca}

Suhu dan kelembapan selama percobaan, menunjukkan bahwa suhu rumah kaca berkisar pada suhu $24{ }^{\circ} \mathrm{C}$ sampai $26{ }^{\circ} \mathrm{C}$ dan kelembapannya berkisar antara 53\% sampai 71\%. Menurut Pathak (1975), $N$. lugens akan hidup sehat pada suhu $25-30{ }^{\circ} \mathrm{C}$ yang berarti populasi $N$. lugens akan melimpah pada kondisi suhu tersebut. Apabila suhu diatas $30{ }^{\circ} \mathrm{C}$, kemungkinan telur tidak akan menetas, sedangkan pada suhu $25-27{ }^{\circ} \mathrm{C}$ banyak telur yang menetas dan tumbuh dengan baik. Menurut Nurbaeti et. al., (2010) dan Sianipar (2018), suhu siang hari yang optimum bagi $N$. lugens yaitu berkisar pada suhu $28-30{ }^{\circ} \mathrm{C}$, sedangkan kelembapan optimal bagi pertumbuhan $N$. lugens yaitu berkisar antara 50-60\% dan kelembapan tinggi yaitu berkisar $70-80 \%$ akan menyebabkan populasi $N$. lugens cepat meningkat.

\section{KESIMPULAN DAN SARAN}

Perlakuan ekstrak etanol daun binahong $(A$. cordifolia) pada konsentrasi $2 \%$ menyebabkan kematian wereng coklat (N. lugens) sebesar 63,75\% pada hari ke-14 setelah perlakuan. Berdasarkan percobaan ini ekstrak daun $A$. cordifolia kurang/tidak efektif terhadap $N$. lugens.

\section{DAFTAR PUSTAKA}

Abizar M, \& Prijono D. 2010. Aktivitas insektisida ekstrak daun dan biji Tephrosia vogelii J.D Hooker (Leguminosae) dan ekstrak buah Piper cubeba L (Piperaceae) terhadap larva Crocodolomia pavonana (F.) (Lepidoptera: Crambidae). Jurnal Hama dan Penyakit Tumbuhan Tropika. 10:1-12.

Anonim. 2011. Brosur Penjelasan Mengenai Insektisida Sidatan $410 \mathrm{Sl}$ dan Sidamethrin 50 EC, Peruntukan, Komoditas dan Hama Targer serta Waktu Aplikasi. Pusat Layanan Pelanggan. PT. Petrosida Gresik.

Anonim. 2015. Produksi Padi Tahun 2014 (Angka Sementara) Diperkirakan Turun 0,63 Persen. http://www.bps.go.id/brs/view/id/1122.

Badan Pusat Statistik. 2017. Rata - rata Konsumsi Beras. Jakarta.

Baehaki SE, \& Mejaya IMJ. 2014. Wereng coklat sebagai hama global bernilai ekonomi tinggi dan strategi pengendaliannya. balai besar penelitian tanaman padi. Subang. Jawa Barat.

Dadang. 2006. Pengenalan pestisida dan teknik aplikasi. workshop hama dan penyakit tanaman jarak. IPB. Bogor.

Efendi E. 2018. Uji efektivitas ekstrak daun dan biji mahoni untuk pengendalian hama wereng coklat pada tanaman padi. Universitas Muhammadiyah Yogyakarta. 
Fitriningtyas W. 2012.Perkembangan populasi dan pembentukan makroptera tiga biotipe wereng batang cokelat Nilaparvata lugens Stal pada sembilan varietas padi.Institut Pertanian Bogor. Bogor.

Fitriyani N. 2017. Efek larvasida larutan senyawa sitral terhadap larva instar III Aedes aegypti. (Skripsi). Universitas Islam Indonesia.

Hariana AH. 2013. Tumbuhan Obat dan Khasiatnya. Departemen Kesehatan RI. Jakarta.

Harini S, Kumar ASS, \& Balaravi P. 2013. Evaluation of rice genotypes for brown planthopper $(\mathrm{BPH})$ resistence using molecular markers and phenotypic methods. African J Biotechnol. 12(19): 2515-2525.

Ismatullah. 2014. Uji efektivitas larvasida ekstrak daun binahong (Anredera cordifolia (Ten.) Steenis) terhadap larva Aedes aegypti instar III. Universitas Lampung.

Kardinan. 2000. Pestisida Nabati: Ramuan dan Aplikasi. Penebar Swadaya. Jakarta.

Katno, Dyah S, Rohmat M, \& Harto W. 2006. Inventaris tanaman obat indonesia. departemen kesehatan badan penelitian dan pengembangan kesehatan. balai penelitian tanaman obat. Jakarta. Hal.16-17.

Kurniawati D, Rustam R, \& Laoh JH. 2015. Pemberian beberapa konsentrasi ekstrak brotowali (Tinospoacrispa L.) untuk mengendalikan keong mas (Pomace asp) pada tanaman padi (Oryza sativa $\mathrm{L}$ ). Jurnal Jom Faperta Vol.2 No.1.Februari 2015.

Maheswaran R, Satish S, \& Ignacinuthu S. 2008. Larvacidal activity of ceucasaspera (willd) against the larvae of Culex quinquefasciatus Say. andAedes aegypti L. Jurnal of Integratif Biology. 2: 3.2155-217.

Manoi F. 2009. Binahong (Anredera cordifolia) (Ten) Steenis) sebagai obat.Jurnal Warta Penelitian Dan Pengembangan Tanaman Industri. 15(1): 3.

Mokodompit T, Koneri R, Siahaan P, \& Tangapo AM. 2013. Uji ekstrak daun thitonia diversifolia sebagai penghambat daya makan Nilaparvata lugens Stal. padaOryza sativa L. Jurnal Bios Logos 3(2): 50-56.

Ningsih NF, Ratnasari E, \& Faizah U. 2016. Pengaruh ekstrak daun kumis kucing (Orthosiphon arisatus) terhadap mortalitas hama wereng coklat (Nilaparvata lugens). LenteraBBio 5(1): 14-19.

Nurbaeti B, Diratmaja IGPA, \& Putra S. 2010. Hama wereng coklat (Nilaprvata lugens Stal) dan pengendaliannya. balai pengkajian teknologi pertanian Jawa Barat. Hlm. 4-29.

Pathak MD. 1975. Insect Pest of Rice.The International Rice Research Intitute. Los Banos, Philippines.

Prakash A. 2001.Antioxidant Activity. Medallion Laboratories: AnalithycalProgres, 19(2):1- 4.
Putri HIS, Farhan A, \& Shofiyah S.2018. Uji efektivitas larvasida ekstrak daun binahong (Anredera cordifolia) pada kematian larva Aedes aegypti. Laporan penelitian kelompok. Sekolah Tinggi Ilmu Kesehatan. Jombang.

Regazzoni O, Sugito Y, \& Suryanto A. 2013. Sistem irigasi berselang (intermittent irrigation) pada budidaya pada budidaya padi (Oryza Sativa L.) varietas inpari-13 dalam pola SRI (Sistem Of Rice Intensification). Jurnal Produksi Tanaman 1 (2): 42-51.

Rizkie L, Herlinda S, \& Suparman. 2015. Serangga hama dan arthropoda predator yang terdapat pada padi lebak di desa pelabuhan dalam kecamatan pemuluatan provinsi Sumatera Selatan. Proseeding Seminar Nasional Lahan Suboptimal. Palembang 8-9 Oktober 2015.

Robinson T. 1995. Kandungan Organik Tumbuhan Tinggi. Edisi IV. Hal.191-216. Diterjemahkan oleh Kosasih Padmawinata.Institut Teknologi Bandung. Bandung.

Rochani N. 2009.Uji aktivitas antijamur ekstrak daun binahong (Anredera cordifolia (Ten) Steenis) terhadap Candida Albicans serta skrining fitokimianya. Universitas Muhammadiyah. Surakarta.

Rossalia D. 2003. Formulasi insektisida botani dari Dysoxylum acutangulum Miq.(Meliaceae).IPB. Bogor.

Setyawati MD. 2018. Uji efektivitas ekstrak biji karet (Hevea brassiliensis) sebagai insektisida hama wereng coklat (Nilaparvata lugens S) pada tanaman padi. Universitas Muhammadiyah Yogyakarta.

Setyorini SD, Shoahuddin \& Sulistyo A. 2013. Existence of brown planthopper's natural enemies on some rice varieties using different cultivation techniques. $\mathrm{J}$ ournal of Agronomy Research 2(5): 8-17.

Sianipar MS. 2018. Fluktuasi populasi serangga wereng coklat (Nilaparvata lugens) pada lahan sawah di kabupaten Karawang Jawa barat. Agrologia, Jawa Barat. 7(2):90-97.

Sutrisno. 2014. Resistensi wereng batang cokelat padi, Nilaparvata lugens Stal terhadap insektisida di Indonesia. Jurnal AgroBiogen. 10(3): 115-124.

Syahrawati, Busniah M, \& Nelly N. 2010. Sosialisasi teknik konservasi musuh alami wereng coklat (Nilaparvata lugens) pada petani perempuan. Lembaga Pengabdian kepada Masyarakat. Unsiversitas Andalas. Padang.

Tuti HK, Wijayanti R, \& Supriyadi. 2014. Efektivitas limbah tembakau terhadap wereng coklat dan pengaruhnya terhadap laba-laba predator. Jurnal Ilmu Ilmu Pertanian Vol. XXIX. No. 1. Universitas Sebelas Maret.

Watanabe T, \& Kitagawa H. 2000. Photosynthesis and translocation of assimilates in rice plants 
following phloem feeding by the planthopper Nilaparvata lugens (Homoptera: Delphacidae). J. Econ. Entomol. 93: 11921198.

Wardani RS, Mifkabakhuddin, \& Yokorinanti K. 2010. Pengaruh ekstrak daun tembelekan (Lantana camara) terhadap kematian larva Aedes aegypti. Jurnal Kesehatan Masyarakat Indonesia.

Wientarsih I, Mustika AA, Wardhana AH, Darmakusumah D, \& Sutardi LN. 2017.
Daun binahong (Anredera cordifolia Steenis) sebagai alternatif insektisida terhadap miasis yang disebabkan lalat Chrymsomya bezziana. Jurnal Veteriner. 1: 121-127.

Wisuda. 2015. Aplikasi ekstrak mimba dengan pelarut alkohol terhadap mortalitas wereng batang coklat (Nilaparvata lugens Stal.). Proseeding seminar nasional Perhimpunan Entomologi Indonesia. Malang 1-2 Oktober 2015. 